\title{
PERANCANGAN CERITA DAN KARAKTER ANIMASI PENDEK BERTEMA FEMINISME
}

\section{Talitha Putri Andira}

\author{
School of Design-Animation, Binus University \\ talithandira@binus.ac.id ${ }^{1)}$
}

\begin{abstract}
A smallest form of feminism act could give a massive impact to the movement itself. In Indonesia, the topic feminism isn't quite widely talked and discussed. There are some traditional customs and rules which suppressed the freedom of choices for not only women, but men as well. Being married against their will, rules and regulations that women have to be kind-hearted, submissive, obedient, loosely-opinionated, and other characters that considered weak. Animation can reach any kind of age and will be able to give morals and message without being too straightforward. In this research, writer did kinds of study with qualitative methodology. This research also leads to design aspect, especially for characters and environments in the short animated film.
\end{abstract}

Keywords: feminism, Indonesia, short animated film, visual. 


\section{PENDAHULUAN}

Feminisme bukanlah keyakinan bahwa satu jenis gender harus berada di atas yang lain. Gerakan feminisme menunjukan penolakan sepenuhnya pada pandangan ini. Hooks (2000, 16) menjelaskan bahwa "Sederhananya, feminisme adalah gerakan untuk mengakhiri seksisme, eksploitasi seksis, dan penindasan.”. Di Indonesia, kesadaran akan isu feminisme sudah ada dari zaman sebelum tokoh emansipasi populer, Kartini, dilahirkan. Sejak dulu, keberpihakan akan satu gender dibandingkan gender lainnya terlihat jelas dari presentase kepemimpinan baik dari zaman sebelum dan sesudah kolonialisme.

Penekanan terhadap hak golongan gender perempuan, yang cenderung lebih minoritas dan lemah di mulai dari suatu hal yang sederhana seperti norma sosial tentang sikap dan perilaku. Pandangan masyarakat akan perempuan yang ideal adalah berperilaku sopan, santun, lembut, taat akan aturan yang ada, tidak boleh bertindak agresif, maupun berbuat hal yang melawan adat setempat. Tak hanya norma bersikap dan berperilaku, hal sekecil berpakaian pun, perempuan harus memenuhi standar tertentu, seperti harus berpakaian sopan dan tertutup, tidak boleh memakai pakaian yang dapat mengakibatkan ketertarikan berlebih dari lawan jenis, dan lain-lain.

Aturan-aturan ini tidak hanya berhenti disitu, contoh penekanan hak gender perempuan yang ekstrem adalah masih adanya kasus pernikahan dini di area rural di Indonesia. Sampai peraturan Undang-Undang Republik Indonesia Nomor 1 Tahun 1974 tentang perkawinan yang pasal-pasalnya berisikan kelegalan seorang suami untuk mempunyai lebih dari 1 istri apabila isteri tidak dapat menjalankan kewajibannya, mempunyai cacat badan, atau tidak dapat melahirkan keturunan. Setelah itu, disebut juga dalam pasal 7, bahwa usia wanita untuk melakukan perkawinan adalah 16 tahun dan laki-laki adalah 19 tahun. Sedangkan batas usia dewasa di Indonesia adalah 18 tahun.

Di dalam Industri perfilman di Indonesia sendiri, karakter perempuan digambarkan cenderung hambar dan repetitif. Dari mulai eksploitasi secara seksual, peran yang cenderung dipinggirkan dalam rumah tangga, sampai karakter yang terlalu ekstrimis. Sedangkan untuk di bagian film animasi, nilai feminisme masih jarang terlihat. Dimulai dari film animasi Homeland pada tahun 2003, sampai Battle of Surabaya masih belum memiliki tokoh wanita yang kuat.

Jika dibandingkan dengan tokoh Merida dari Pixar, Mulan, Tiana, dan Moana dari Disney, serta San, Chichira, juga Kiki dari Studio Ghibli, Indonesia masih tergolong lemah dalam pengembangan karakter dan cerita yang mengelilingi sosok perempuan yang tangguh dan heroic.

Sadar akan hal itu, penulis terinspirasi untuk membuat cerita tentang sosok perempuan yang kuat dengan mengambil Indonesia sebagai latarnya dan mengangkatnya menjadi sebuah film animasi pendek. Penulis berharap pesan akan isu feminisme dapat dimengerti dan disadari oleh penonton melalui sajian secara visual. Ekspektasi dari penelitian ini adalah, penulis dapat lebih memahami tentang isu feminisme yang berkembang di Indonesia dan mengumpulkan data valid melalui wawancara narasumber yang terkait dengan topic feminisme, seperti aktivis feminis maupun organisasi atau yayasan yang bersifat dan bergerak di bidang pembelaan kesetaraan gender.

Selain riset akan topik feminisme itu sendiri, penulis juga mengkaji kultur, adat, dan setting lokal Indonesia yang menarik dan dapat diangkat menjadi latar 
belakang film animasi pendek. Penelitian terhadap film yang memiliki tema yang mirip juga dilakukan agar dapat menghasilkan konsep cerita yang menarik.

\section{Kajian Literatur}

Teori Unsur Cerita

Screenwriter, Karl Iglesias (2008) meyebutkan definisi pendek dan jelas dari cerita, "Sebuah cerita memiliki seseorang yang sangat menginginkan sesuatu dan mengalami kesulitan mendapatkannya." Definisi ini menentukan tiga elemen primer yang penting dalam membuat suatu cerita, yaitu:

1. Character: subyek utama dari cerita dan melalui sudut pandangnyalah cerita tersebut dilihat.

2. Goal: objek/tujuan yang ingin dicapai oleh karakter di dalam cerita tersebut.

3. Conflict: suatu hal yang menghalangi atau berada di antara character dan goal. Konflik itu sendiri memiliki tiga jenis yaitu: character vs. character, character vs. environment, character vs. self. Konflik menciptakan suatu masalah, rintangan, dan dilema yang menaruh karakter di dalam suatu keaadaan yang berbahaya, baik secara fisik, mental, atau spiritual. Ini berarti bahwa akan ada akibat yang ditanggung oleh karakter jika dia tidak bisa melalui konflik tersebut.

Elemen lain dari sebuah cerita adalah sebagai berikut:

1. Location: Lokasi adalah sebuah tempat, periode waktu, atau atmosfer yang mendukung cerita.

2. Inciting Moment: Di dalam setiap cerita, dunia atau hidup dari karakter terlihat normal pada awalnya, sampai suatu saat sesuatu yang tidak terduga terjadi. Kejadian yang tak terduga ini adalah awal dari cerita.

3. Story Question: Kejadian yang tidak terduga akan menimbulkan pertanyaan di pikiran penonton yang harus dijawab di akhir cerita.
4. Theme : Cerita memiliki arti khusus bagi karakter dan penonton. Tema atau konsepnya adalah gagasan yang lebih mendasar yang dikomunikasikan oleh animasi tersebut. Tema adalah makna cerita yang lebih mendalam.

5. Need: Agar cerita memiliki makna bagi karakternya, karakter tersebut perlu memiliki kebutuhan untuk mencapai tujuan.

6. Arc: Saat karakter melewati masalahmasalah dan belajar dari masalah tersebut, terjadi gejolak emosi atau perubahan karakter.

7. Ending/Resolution : Akhir dari ceritanya harus diberikan ke penonton untuk menciptakan kelegaan secara emosional dan memberikan jawaban pada pertanyaan dari cerita tersebut. Akhir cerita harus memberikan efek yang kuat terhadap penonton.

\section{Ide/Cerita}

Pada abad ke-20, Joseph Campbell, seorang profesor mitologi, penulis, dan orator asal Amerika, mulai berpikir bahwa dia memahami alasan untuk kesamaan dalam cerita yang melampaui pengalaman fenomena eksternal. Campbell bekerja di bidang mitologi komparatif dan perbandingan agama yang mempelajari tentang cerita. Dia meneemukan bahwa ada gambaran dan karakter universal yang dalam satu cerita yang dimiliki oleh semua budaya sepanjang periode waktu. Karena cerita ini terjadi berulang kali, dia menamainya dengan sebutan monomyth yang berarti the one story dan cerita universal.

Monomyth berisi tentang cerita seorang hero yang biasa disebut "the Hero's Journey". Berikut adalah tingkatan cerita dari teori Campbell (dalam mr x, 2000):

1. Introduce the Hero : Cerita berisikan tentang Hero sebagai subyek utama. Hero ini diceritakan sedang 
mengalami hari yang biasa dalam kehidupannya.

2. The Hero has a Flaw: Penonton harus mempunyai rasa empati kepada hero ini dan ikut tergabung secara emosional dalam perjalanan ceritanya. Jadi, hero di cerita ini tidaklah sempurna. Dia mempunyai kekurangan yang akan berakibat pada kegagalannya atau kesuksesannya.

3. Unexpected Event : sesuatu yang tak disangka terjadi yang berdampak pada perubahan dalam hidup dari hero tersebut.

4. Call to Adventure : karakter hero harus mencapai tujuannya. Sering kali sang hero enggan untuk mengambil risiko dalam perjalanannya. Disini mulai bermunculan karakter baru yang akan ditemui hero seperti mentor, teman, dan sekutu yang akan mendukungnya.

5. The Quest : Sang hero meninggalkan dunianya demi mencapai tujuannya. Disini, karakter hero akan mengalami ujian, percobaan, musuh, dan rintangan sampai mendapatkan tujuannya.

6. The Return : Sang hero akan kembali ke dunianya dan berekspektasi untuk mendapatkan penghargaan.

7. The Crisis : terjadi suatu masalah, karakter hero mengalami saat yang paling terpuruk dalam ceritanya.

8. The Showdown : karakter hero harus menghadapi rintangan/masalah terakhir, biasanya berkaitan dengan hidup dan mati melawan musuh terbesarnya. Dia harus menggunakan segala kemampuan yang dipelajarinya saat berpetualang untuk berhasil melewatinya.

9. The Resolution : di film, biasanya cerita berakhir dengan bahagia, dan pada akhirnya hero berhasil melalui rintangannya.
Data hasil Wawancara

Penulis melakukan wawancara dengan pemimpin redaksi Yayasan Jurnal Perempuan, yang juga merupakan seorang aktivis feminis, Anita Dhewy. Yayasan yang didirikan oleh Dr. Gadis Arivia, Prof. Dr. Toeti Heraty NoerhadiRoosseno, Ratna Syafrida Dhanny, dan Asikin Arif ini berdiri sejak tahun 1995 dengan menerbitkan Jurnal Perempuan, merupakan jurnal feminis pertama di Indonesia yang dibaca kalangan mahasiswa, pengambil kebijakan, intelektual, akademisi dan aktivis gerakan sosial.

Berdasarkan hasil dari wawancara Ibu Anita, penulis menyimpulkan data sebagai berikut:

1. Kesadaran akan isu feminisme dan keberpihakan gender di Indonesia masih minim, terlihat dari presentase kepemimpinan di Indonesia, baik dari kepala daerah, kabinet menteri, sampai presidensi yang masih didominasi gender tertentu. Selain itu, UU Republik Indonesia sendiri tidak membantu banyak dalam kasus ini, seperti contohnya, undang-undang perkawinan yang sebenarnya merugikan wanita karena diperbolehkannya poligami dan pernikahan dibawah umur.

2. Isu tentang menikah paksa, menikah di bawah umur, kekerasan dalam rumah tangga, dan perkosaan terhadap wanita itu sebenarnya masih sangat banyak terjadi di Indonesia zaman modern. Kejadian "victim blaming" membuat isu-isu ini jadi terpendam dan banyak korban yang enggan untuk angkat bicara.

3. "Musuh" dari para feminis berbeda seiring berjalannya zaman. Dulu, sebelum masa reformasi, lawan dari para feminis adalah sosok otoriter/patriarki, sedangkan untuk zaman sekarang, lawannya lebih cenderung mengarah ke masyarakat, 
bahkan lingkup sosial sekitar kita sendiri.

4. Untuk menyadarkan Indonesia akan isu feminisme, bukan dengan cara mengedukasi wanita/pihak yang dirugikan dalam hal ini, melainkan mengedukasi masyarakatnya agar sadar akan tindakan seksisme yang mereka lakukan.

\section{Feminisme}

Feminisme bukanlah keyakinan bahwa satu jenis gender harus berada di atas yang lain. Definisi feminisme menunjukkan penolakan sepenuhnya terhadap kepercayaan ini. Gerakan ini bukan tentang anti-laki-laki, tetapi gerakan yang memperjuangkan kesetaraan gender. Menurut Hooks (2000), "sederhananya, feminisme adalah gerakan untuk mengakhiri seksisme, eksploitasi seksis, dan penindasan." Jadi ketika orang berkomentar hal-hal yang melawan feminisme, mereka mendukung seksisme, eksploitasi seksis dan penindasan.

Pada dasarnya, feminisme itu sendiri adalah teori bahwa pria dan wanita harus setara secara politik, ekonomi dan secara sosial. Sedangkan feminis adalah orang yang percaya dan mendukung gerakan feminisme.

Menurut Bell Hooks, Feminist Theory: From Margin to Center, 1984, feminisme adalah perjuangan untuk mengakhiri penindasan seksis. Oleh karena itu, perlu adanya perjuangan untuk memberantas ideologi dominasi yang merasuki budaya Barat pada berbagai tingkatan sekaligus komitmen untuk menata ulang masyarakat sehingga pengembangan diri manusia dapat diutamakan daripada imperialisme, perluasan ekonomi, dan keinginan material. Ditetapkan dengan cara ini, tidak mungkin wanita akan bergabung dalam gerakan feminis hanya karena kita secara biologis sama. Komitmen terhadap feminisme yang didefinisikan demikian menuntut agar masingmasing peserta memperoleh kesadaran politik kritis berdasarkan gagasan dan keyakinan. (p. 24)

Feminisme bertujuan bukan untuk hanya menguntungkan sekelompok wanita tertentu, kelompok tertentu atau kelas perempuan. Ini tidak memberi hak istimewa kepada wanita atas pria. Ini memiliki kekuatan untuk berubah dalam cara yang berarti sepanjang hidup kita.

\section{Existing Study}

Studi Cerita Moana

Feature animated film ini adalah film dari Disney yang bercerita seputar kehidupan seorang karakter wanita tanpa memiliki love interest. Film ini memotret perjuangan karakter utama, Moana, untuk menyelamatkan dan mengembalikan kesuburan di desanya. Disini, Moana bukan hanya dihadapkan oleh rintangan outsider, tetapi juga dari inner circle, yaitu keluarganya sendiri yang melarang Moana untuk pergi menyelamatkan desanya.

Nilai feminisme sangat kuat terlihat dari film ini, dimulai dari pemberian gambaran akan sosok hero perempuan yang kuat dengan berfokus pada perjuangan Moana tanpa dibumbui romantic relationship maupun sosok pria penyelamat seperti prince di film Snow White and the Seven Dwarves atau Sleeping Beauty.

\section{Studi Cerita Brave}

Film animasi lainnya dari Disney yang berfokus pada karakter wanita tanpa sosok penyelamat. Karakter utama di film ini, Merida digambarkan sebagai sosok pemberontak tradisi turun temurun seorang putri penguasa, yaitu menikah dengan putra penguasa daerah lainnya. Merida menolak tunduk pada aturan 
patriarki dan memilih untuk bebas menjalani hidupnya tanpa diatur oleh pria manapun.

Di film ini, lawan atau musuh dari karakter utama bukan dari lingkungan luar, melainkan dari lingkungan internal, lebih spesifiknya adalah ibunya sendiri, seorang wanita yang juga dulunya dipaksa tunduk akan adat. Dinamika dari interaksi kedua karakter ini sangat menarik dan memberi pesan bahwa lawan terbesar dari tokoh hero itu adalah kawanan mereka sendiri yang tertundukan oleh patriarki dan aturan sosial.

\section{Studi Cerita Spirited Away}

Spirited Away adalah petualangan tentang seorang gadis bernama Chihiro yang bermula saat dia dan orang tuanya terjebak dalam dunia roh. Chiciro harus mencari cara untuk menyelamatkan orang tua dan dirinya sendiri dari tempat itu.

Sisi menarik dari film ini adalah figur karakter utama yang realistis, pada awal cerita digambarkan sebagai pribadi yang malas dan manja, tapi pada akhirnya bangkit sebagai pahlawan dari cerita tersebut. Bahkan karakter utama ini berhasil menyelamatkan karakter lainnya yang pada awal cerita membantu perjalanannya. Cichiro pun dipotret dengan seluruh kekurangan yang dimiliki seorang gadis kecil biasa, tidak seperti classic Disney princess yang cenderung sempurna secara fisik maupun perilaku.

\section{Studi Visual Karakter}

Untuk studi visual karakter, penulis menganalisa bentuk dan atribut dari feature animated film Moana dan Mulan, serta short animated film Burn Out dan Mehua.

\section{METODE PENELITIAN DAN PERANCANGAN}

\section{Metode Penelitian}

Pendekatan yang akan dilakukan penulis dalam penelitian ini adalah cara kualitatif. Data yang akan dikumpulkan bukan berupa angka atau numerik, melainkan berupa literatur dari berbagai macam buku mengenai kisah para tokoh pahlawan feminisme Indonesia, dan budaya serta lokasi-lokasi menarik di Indonesia. Yang menjadi tujuan dari penelitian kualitatif ini adalah untuk menghasilkan deskripsi yang detail tentang kehidupan para tokoh terkait, budaya, setting dari Indonesia agar dapat menjadi inspirasi untuk pembuatan karakter dan story line yang dibutuhkan oleh short animation.

Pada hakikatnya penelitian deskriptif kualitatif adalah suatu metode dalam meneliti status sekelompok manusia, suatu objek dengan tujuan membuat deskriptif, gambaran atau lukisan secara sistematis, faktual dan akurat mengenai fakta-fakta atau fenomena yang diselidiki.

Penelitian kualitatif menekankan pada kedalaman data yang didapatkan oleh peneliti. Semakin dalam dan detail data yang didapatkan, maka semakin baik kualitas dari penelitian kualitatif ini. Untuk itu hasil dari penelitian ini memerlukan kedalaman analisis dari peneliti. Selain itu, hasil penelitian ini bersifat subjektif sehingga tidak dapat digeneralisasikan.

\section{Metode Perancangan}

Menurut Ambrose dan Harris (2010), dalam proses perancangan desain, ada 7 tahap yang penting:

\section{Define}

Proses ini adalah tahap pertama dalam setiap proses desain. Pemahaman yang tepat akan masalah yang ada dapat menghasilkan berbagai alternatif solusi 
yang sesuai. Tahap ini menentukan sukses atau tidaknya suatu proyek. Proses ini dapat dibantu dengan mengaplikasikan 5W dan $1 \mathrm{H}$ (Who, What, When, Where, Why, How). Dengan menggunakan metode tersebut, desainer dapat memberikan detail yang dapat digunakan selama proses perancangan dan mengidentifikasi masalah yang harus diselesaikan.

\section{Research}

Setelah masalah telah didefinisikan, desainer mulai mencari informasi yang dapat diolah ke dalam proses kreatif selanjutnya, ideate. Penelitian ini dapat berupa kuantitatif yang bersifat numerik, dan kualitatif yang bersifat deskriptif. Data yang dihasilkan dari proses riset ada 2 , yaitu data primer, yang didapatkan dari wawancara langsung dengan narasumber, sedangkan data sekunder adalah dari sumber literature yang sudah ada ataupun riset sebelumnya yang berkaitan dengan topic bahasan.

\section{Ideate}

Informasi yang dikumpulkan di tahap research digunakan untuk membuat gagasan atau ide untuk rancangan desain. Proses ini pada dasarnya menciptakan alternatif solusi yang potensial. desainer menggunakan 3 metode yang berbeda untuk ideate. Metode ideate meliputi brainstorming, membuat sketsa dari ide-ide, mengadaptasi referensi desain yang sudah ada dan telah teruji, mengambil pendekatan analitik top-down yang berfokus pada produk, layanan, perusahaan, maupun pendekatan bottomup yang berfokus pada pelanggan atau pengguna.

\section{Prototype}

Tahap ideate menghasilkan berbagai solusi dan ide yang berpotensi untuk menghasilkan desain yang sesuai. Sebuah prototype dapat digunakan untuk menguji kelayakan teknis dari sebuah ide desain untuk melihat apakah ia bekerja sebagai objek fisik. Sebuah prototype juga dapat menguji aspek visual dari desain tersebut dengan mempresentasikannya seperti yang akan dihasilkan. Tahap ini juga memberi kesempatan untuk menguji (jika diperlukan) desain dalam bentuk tiga dimensi. Sebuah prototype memberi kemampuan untuk memvisualisasikan dan menangani konsep desain, untuk mendapatkan gambaran tentang fisik dan kualitasnya.

\section{Select}

Tahap ini adalah tentang membuat pilihan. Select adalah tahap di mana salah satu solusi desain yang telah ada dipilih untuk dilanjutkan ke proses pengembangan. Kriteria keputusan utama adalah yang paling cocok untuk tujuan desain: apakah desain memenuhi kebutuhan dan tujuan, dan apakah desain akan secara efektif berkomunikasi dengan audiens?

\section{Implement}

Selama tahap ini, desainer memberikan hasil karya desain dan spesifikasi format kepada mereka yang akan melakukan produksi akhir. Implementasikan adalah tahap dimana perancang memberikan solusi dan hasil final desain.

\section{Learn}

Mendapatkan feedback adalah inti dari tahap ini. Tahap akhir dalam proses ini melibatkan pembelajaran dari apa yang telah terjadi selama proses perancangan. Ini adalah tahap feedback di mana desainer berusaha untuk mengidentifikasi apa yang berhasil dengan baik dan perbaikan. Setelah diimplementasikan, klien mungkin mulai mencari atau menerima umpan balik mengenai bagaimana produk telah diterima oleh target pemirsa dan seberapa menguntungkan dampaknya terhadap 
target pemirsa. Dengan demikian, sebuah perusahaan perancang dapat mengetahui bagaimana audiens menanggapi disain.

\section{Ruang Lingkup Penelitian}

Ruang lingkup penelitian dibatasi hingga definisi feminisme dan pergerakannya di Indonesia, pengaruhnya terhadap dinamika sosial, cara menaikan awareness dari masyarakat serta pembelajaran akan sejarah tokoh-tokoh feminisme Indonesia dan budaya Indonesia. Kemudian informasi tersebut dirangkai menjadi landasan dalam membentuk storyline dan karakter untuk film animasi pendek.

\section{HASIL DAN PEMBAHASAN}

\section{Data hasil Wawancara}

Penulis melakukan wawancara dengan pemimpin redaksi Yayasan Jurnal Perempuan, yang juga merupakan seorang aktivis feminis, Anita Dhewy. Yayasan yang didirikan oleh Dr. Gadis Arivia, Prof. Dr. Toeti Heraty NoerhadiRoosseno, Ratna Syafrida Dhanny, dan Asikin Arif ini berdiri sejak tahun 1995 dengan menerbitkan Jurnal Perempuan, merupakan jurnal feminis pertama di Indonesia yang dibaca kalangan mahasiswa, pengambil kebijakan, intelektual, akademisi dan aktivis gerakan sosial.

Berdasarkan hasil dari wawancara Ibu Anita, penulis menyimpulkan data sebagai berikut:

1. Kesadaran akan isu feminisme dan keberpihakan gender di Indonesia masih minim, terlihat dari presentase kepemimpinan di Indonesia, baik dari kepala daerah, kabinet menteri, sampai presidensi yang masih didominasi gender tertentu. Selain itu, UU Republik Indonesia sendiri tidak membantu banyak dalam kasus ini, seperti contohnya, undang-undang perkawinan yang sebenarnya merugikan wanita karena
diperbolehkannya poligami dan
pernikahan dibawah umur.

2. Isu tentang menikah paksa, menikah di bawah umur, kekerasan dalam rumah tangga, dan perkosaan terhadap wanita itu sebenarnya masih sangat banyak terjadi di Indonesia zaman modern. Kejadian "victim blaming" membuat isu-isu ini jadi terpendam dan banyak korban yang enggan untuk angkat bicara.

3. "Musuh" dari para feminis berbeda seiring berjalannya zaman. Dulu, sebelum masa reformasi, lawan dari para feminis adalah sosok otoriter/patriarki, sedangkan untuk zaman sekarang, lawannya lebih cenderung mengarah ke masyarakat, bahkan lingkup sosial sekitar kita sendiri.

4. Untuk menyadarkan Indonesia akan isu feminisme, bukan dengan cara mengedukasi wanita/pihak yang dirugikan dalam hal ini, melainkan mengedukasi masyarakatnya agar sadar akan tindakan seksisme yang mereka lakukan.

\section{Penulisan Judul "Maka"}

Visual desain dari judul film animasi pendek ini, penulis menggunakan font "Dythia" yang memiliki struktur bentuk yang menyerupai huruf lontar, huruf yang dipakai dalam penulisan naskah kuno suku Bugis.

\section{N. $A K \wedge$ \\ Gambar 1. Typeface Judul}

\section{Perancangan Tokoh Karakter}

Tokoh utama di dalam cerita film pendek animasi ini adalah Makatenga Tenri Ola, diambil dari bahasa bugis, dan dipendekan menjadi Maka. Makatenga itu sendiri berarti "berada di tengah, adil, 
persamaan", sedangkan Tenri hanya boleh dipergunakan oleh putri keturunan bangsawan di suku Bugis, dan Ola berarti "memberikan jalan atau maju kedepan", beberapa versi mengatakan Ola berarti ambisius dan inovatif.

Kepribadian, semangat perjuangan, dan latar belakang hidup dari Maka sangat terinspirasi dari tokoh pejuang perempuan dari tanah Sulawesi Selatan, Siti Aisyah We Tenri Olle yang merupakan pemimpin kerajaan Tanete pada zaman kolonial Belanda. Beliau juga merupakan pendiri sekolah pertama bagi perempuan di kampung halamannya dan mempunyai peran besar dalam menyelamatkan dan menerjemahkan epos I La Galigo yang merupakan peninggalan nenek moyang Bugis dan kini diakui sebagai warisan sastra dunia. Kisah beliau menjadi inspirasi utama dalam pembuatan karakter dan story line dari film animasi pendek ini.

Maka Kecil

Di sini, karakter maka kecil digambarkan sebagai seorang anak berumur 6-8 tahun yang memiliki karakter periang, berani, dan mempunyai rasa penasaran yang sangat tinggi. Sifat kekanak-kanakan dan keteledoran masih terlihat dari Maka kecil dari cara karakter ini bergerak, berpose, dan berekspresi wajah. Maka kecil mengenakan pakaian tradisional khas suku Bugis, Sulawesi Selatan, yaitu baju bodo. Setiap warna di baju bodo ini memiliki arti tersendiri. Warna merah yang dikenakan Maka kecil biasa digunakan oleh gadis kecil nonbangsawan yang belum menginjak puberitas. Tujuan penggunaan warna merah ini, walaupun Maka adalah seorang putri bangsawan yang seharusnya warna hijau, adalah bentuk 'pemberontakan' terhadap aturan kerajaan karena Maka kecil yang tidak menginginkan perbedaan dirinya dan anak lain seusianya. Rambutnya pun yang pendek bebas tergerai, berbeda dari anak perempuan lainnya yang diharuskan untuk disanggul dan berambut panjang.

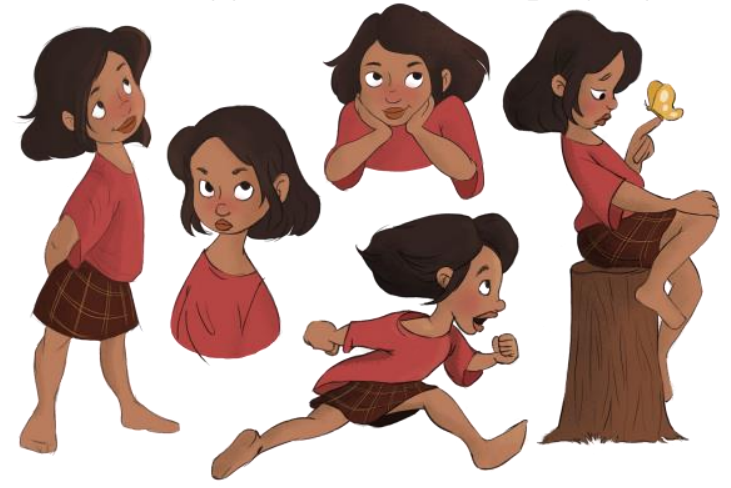

Gambar 2. Konsep Maka Kecil

Maka remaja

Maka remaja berumur sekitar 16-18 tahun. Sikapnya mulai dewasa dan cenderung tertahan aturan-aturan yang ada. Gerak-geriknya pun bertransisi menjadi lebih anggun dan kurang ekspresif. Pada fase ini, sikap Maka telah tertunduk oleh tekanan dari budaya dan aturan cara berperilaku sebagai selayaknya seorang gadis berdarah biru baik dari ibunya, maupun dari masyarakat. Rambutnya terlihat lebih sering di sanggul, seperti kebanyakan wanita, dan baju bodo tradisional yang dikenakannya berlengan panjang dan berwarna hijau, dihiasi motif dan aksesoris emas menunjukan darah kebangsawanannya.

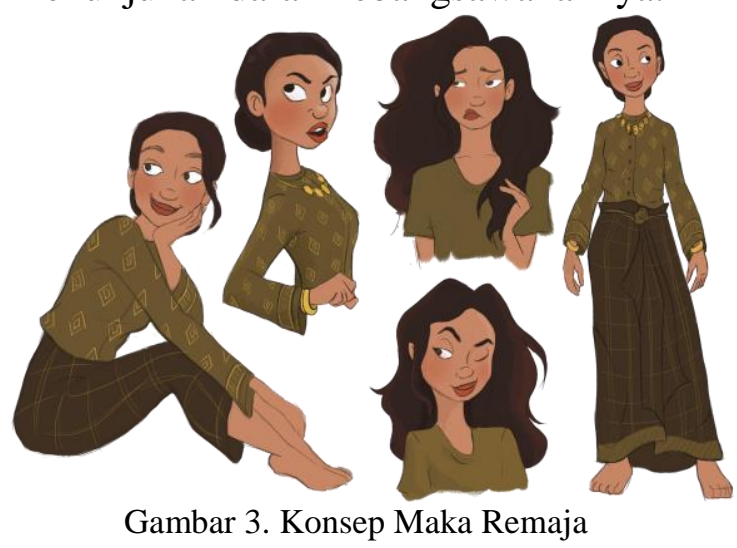

\section{Environment}

Film pendek animasi ini mengambil latar belakang dari kehidupan tropis di Sulawesi Selatan. Beberapa latar tempat sangat terinspirasi dari kehidupan 
masyarakat suku Bugis di zaman kolonial Belanda. Scene dari film animasi pendek ini akan menggunakan 4 setting lokasi.

Rumah Maka

Karena berasal dari keluarga bangsawan, rumah Maka cenderung besar dan luas, serta memiliki lorong panjang dengan dinding penuh dengan lukisan tetua dan pemimpin suku Bugis pada masa itu. Di bagian depan rumah itu ada ruangan singgasana kerajaan sedangkan di bagian belakang terdapat kamar Maka. Maka dan perempuan lainnya yang tinggal disitu, termasuk Ibunya dan pelayan-pelayan, dilarang untuk kedepan rumah kecuali ada acara adat atau acara penting. Bagian depan rumah hanya diperbolehkan untuk lakilaki.

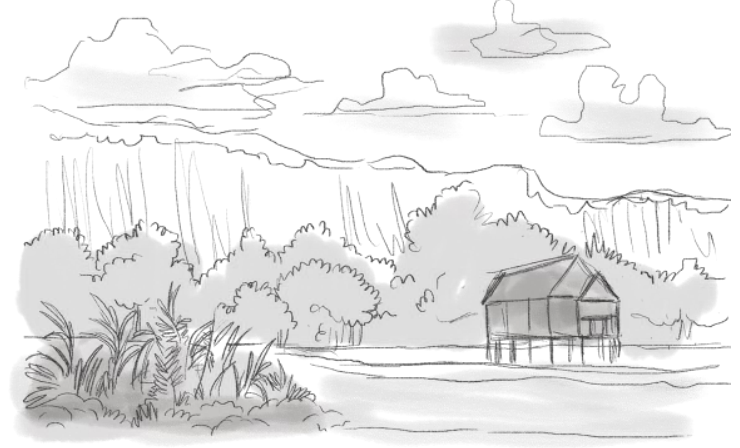

Gambar 4. Konsep Rumah Maka

Hutan

Hutan yang digambarkan disini adalah hutan tropis yang lebat dengan banyak pohon yang berdiameter beragam dan daun-daun padat memberikan kesan 'dunia yang berbeda' dari luar hutan. Di hutan ini juga banyak tinggal fauna endemik seperti burung Julang dan berbagai spesies kupu-kupu yang akan sesekali muncul dalam beberapa scene. Tak hanya visual pohon hijau rindang, tapi sungai dan batu-batu juga akan muncul dalam beberapa scene. Di hutan ini akan banyak scene interaksi antara Maka kecil dan Maka remaja.

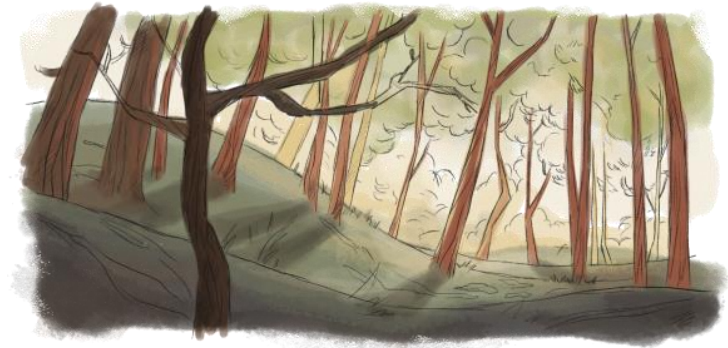

Gambar 5. Konsep Hutan

Karst

Salah satu lokasi paling terkenal di Sulawesi Selatan adalah hutan batu karst terluas kedua di dunia, karst MarosPangkep. Saat menaiki karst ini sampai puncaknya, Maka dapat melihat seluruh pemandangan tempat tinggalnya dan sekitar. Disini adalah tempat dimana Maka kecil dan Maka besar merenung dan menghabiskan waktu bersama saat senja. Angin sepoi-sepoi dan pemandangan matahari tenggelam menghadirkan efek visual yang tenang.

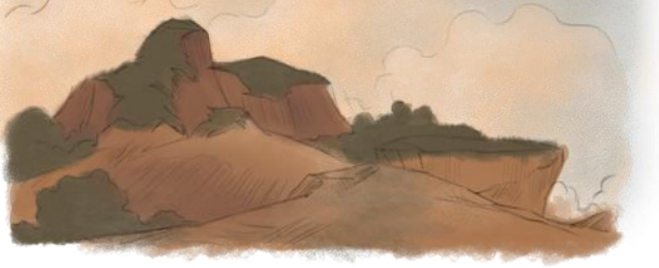

Gambar 6. Konsep Karst
Rumah pohon

Rumah pohon ini berlokasi di dalam hutan. Rumah kecil ini dibangun seadanya dengan lempengan kayu yang disusun dan bertopang pada cabangcabang pohon besar. Di dalam rumah ini terdapat banyak barang peninggalan kakek Maka, yang merupakan seorang Raja atau pemimpin suku berupa aksesoris kerajaan, baju, lembaranlebaran daun lontar yang bertuliskan kisah-kisah sejarah, sampai senjata tradisional kebangsawanan.

Pada scene menuju akhir cerita, Maka remaja memasuki rumah pohon ini 
dan menemukan kembali barang-barang kakeknya yang telah lama hilang dan lukisan-lukisan potret kebersamaannya dan kakeknya. Luapan emosional mulai terjadi di setting ini.

\section{SIMPULAN}

Penelitian dalam proses perancangan ini sangat penting untuk menjadi pendukung dan landasan ide untuk pesan yang ingin disampaikan. Tugas dari penulis disini adalah untuk mengaplikasikan informasi dan data yang telah dikumpulkan menjadi visual film pendek animasi. Karya yang dihasilkan juga harus memiliki makna dan arti dan dapat dimengerti oleh target penonton.

Dalam proses perancangan ini, penulis sendiri melakukan riset literatur dan wawancara para ahli sehingga informasi tersebut dapat dipertanggungjawabkan dan bias dijadikan landasan yang baik untuk pembuatan film animasi pendek. Ide utama dari cerita ini adalah penemuan kembali jati diri seorang gadis pejuang feminis. Nilai dan aturan patriarki yang menundukan bukan hanya perempuan, tapi juga laki-laki belum banyak dibahas dan diperbincangkan di Indonesia. Masih banyak juga komunitas atau grup tertentu yang mengatasnamakan tradisi atau aturan norma sosial untuk melakukan tindakan yang sebenarnya adalah seksis. Oleh karena itu, penulis membuat film animasi pendek yang dapat memberikan pesan tersirat akan isu tersebut.

\section{DAFTAR PUSTAKA}

\section{Sumber Buku}

Ambrose, G. dan Harris, P. (2015). Design Thinking for Visual Communication. London: Bloomsbury Publishing Plc.
Alexander, K., Schumer, G. \& Sullivan, K. (2008). Ideas for the Animated Short. Burlington: Focal Press.

Hooks, B. 1984. Feminist Theory from Margin to Center. Boston: South End Press.

Hooks, B. (2000). Feminism is for Everybody, Passionate Politics. Cambridge: South End Press.

Motta, S, \& etc. (2011). Feminism, Women's Movements and Women in Movement. A journal for and about social movements, Volume 3 (2): 1-32.

\section{Sumber Internet}

Dargis, M., \& Scott, A. O. (2014). Sugar, Spice and Guts: Representation of Female Characters in Movies Is Improving, diakses 22 November 2017 dari https://www.nytimes.com/2014/0 9/07/movies/fall-arts-previewrepresentation-of-femalecharacters-in-movies-isimproving.html?mcubz $=0$

Azkiya, G. (2016). Sosok dan Makna di Balik Kehadiran Wanita, diakses 22 November 2017 dari

https://muda.kompas.id/2016/05/15/soso k-dan-makna-dibalik-kehadiranwanita/

Guitron, S. (2013). Messages from Japan's Most Famous Animator: Feminist and Environmentalist Themes in Miyazaki's Nausicä̈ of the Valley of the Wind and Spirited Away, diakses 22 November 2017 dari http://cmsw.mit.edu/angles/2013/ ?page $\mathrm{id}=94$ 